\title{
In vivo and in vitro maturation of rabbit oocytes differently affects the gene expression profile, mitochondrial distribution, apoptosis and early embryo development
}

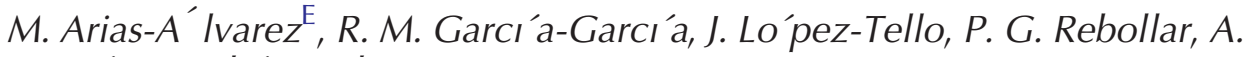 \\ Gutie'rrez-Ada'n and P. L. Lorenzo
}

\begin{abstract}
In vivo-matured cumulus-oocyte complexes are valuable models in which to assess potential biomarkers of rabbit oocyte quality that contribute to enhanced IVM systems. In the present study we compared some gene markers of oocytes and cumulus cells (CCs) from immature, in vivo-matured and IVM oocytes. Moreover, apoptosis in CCs, nuclear maturation, mitochondrial reallocation and the developmental potential of oocytes after IVF were assessed. In relation to cumulus expansion, gene expression of gap junction protein, alpha 1, $43 \mathrm{kDa}$ (Gjal) and prostaglandin-endoperoxide synthase 2 (Ptgs2) was significantly lower in CCs after in vivo maturation than IVM. In addition, there were differences in gene expression after in vivo maturation versus IVM in both oocytes and CCs for genes related to cell cycle regulation and apoptosis (V-Akt murine thymoma viral oncogene homologue 1 (Akt1), tumour protein 53 (Tp53), caspase 3, apoptosisrelated cysteine protease (Casp3)), oxidative response (superoxide dismutase 2, mitochondrial (Sod2)) and metabolism (glucose-6-phosphate dehydrogenase (G6pd), glyceraldehyde-3-phosphate dehydrogenase (Gapdh)). In vivo-matured CCs had a lower apoptosis rate than IVM and immature CCs. Meiotic progression, mitochondrial migration to the periphery and developmental competence were higher for in vivo-matured than IVM oocytes. In conclusion, differences in oocyte developmental capacity after IVM or in vivo maturation are accompanied by significant changes in transcript abundance in oocytes and their surrounding CCs, meiotic rate, mitochondrial distribution and apoptotic index. Some of the genes investigated, such as Gjal, could be potential biomarkers for oocyte developmental competence in the rabbit model, helping improve in vitro culture systems in these species.
\end{abstract}

\section{Introduction}

Oocyte maturation is a crucial process for species survival, during which oocytes acquire their intrinsic capacity to support the subsequent stages of development, namely fertilisation and early embryo development (Eppig et al. 1997). In rabbit, IVM is a useful tool in biotechnology to produce somatic cell nuclear transfer (SCNT) embryos, for animal breeding, for studies of developmental biology and as a model system for human reproduction (Fischer et al. 2012). Despite the importance of rabbits as laboratory animal models, the efficiency of IVM remains very low in this species compared with other species because of the limited information available regarding the cellular and molecular mechanisms controlling oocyte maturation in rabbits.

It is well known that the several layers of cumulus cells (CCs) surrounding the oocyte play an essential function in follicular development and oocyte cytoplasmic maturation (Buccione et al. 1990). Indeed, the oocyte plays a dominant role in regulating the functions of CCs during folliculogenesis and it is therefore believed that the quality of CCs indirectly reflect an oocyte's competence (Eppig et al. 1997). Consequently, gene expression analysis in CCs provides a non-invasive method for 
identification of the most competent oocytes for assisted reproductive technologies (ARTs). In recent years, several studies in animal models (Nivet et al. 2013; Blaha et al. 2015; Shao et al. 2015) and humans (McKenzie et al. 2004; Adriaenssens et al. 2010; Assou et al. 2010; Li et al. 2015) have tried to identify candidate genes expressed in CCs that could be used as biomarkers of oocyte quality. In this sense, some studies have focused on identifying differences in gene expression between IVM and in vivo-matured cumulus-oocyte complexes (COCs) in many species, including dogs (Cho et al. 2016), cattle (Tesfaye et al. 2009; Adona et al. 2016), mice (Cecconi et al. 2010) and humans (Jones et al. 2008; Ouandaogo et al. 2012). The results from these studies show that the expression of transcripts in CCs and oocytes is altered by in vitro conditions, giving rise to developmentally incompetent oocytes. Therefore, in vivo-matured COCs are a good reference to identify biomarkers of high oocyte developmental competence in CCs to improve the IVM protocols in animals and humans. However, limited data are available regarding gene expression profiles in association with oocyte maturation and, in some cases, the genes proposed as biomarkers exhibit differences in expression between studies (Burnik Papler et al. 2015). To the best of our knowledge, there is no information regarding these markers in rabbit models in the literature.

The complex events that occur during mammalian oocyte maturation include a coordinated nuclear and cytoplasmic maturation process (Sirard 2001). Nuclear maturation can be easily assessed because it is characterised by meiotic resumption, accompanied by $\mathrm{CC}$ expansion, meiotic progression until MII and release of the first polar body. Thereby, gene expression profiles of genes related to cumulus expansion, such as gap junction protein, alpha $1,43 \mathrm{kDa}$ (Gjal) and prostaglandinendoperoxide synthase 2 (Ptgs2), have been proposed as suitable biomarkers for predicting pregnancy (Feuerstein et al. 2007; Hasegawa et al. 2007; Li et al. 2015; Shao et al. 2015). However, molecular events and reorganisation of organelles that occur during cytoplasmic maturation are difficult to evaluate and deserve further investigation.

Conversely, mitochondrial relocation in the oocyte has been widely used in several species to estimate oocyte cytoplasmic maturation because meiotic progression and CC expansion are accompanied by changes in the distribution of active mitochondria (Bavister and Squirrell 2000). These organelles play an important role in ATP synthesis by oxidative phosphorylation and are involved in the antioxidant defence of the oocyte (Dumollard et al. 2009). In vitro culture conditions are associated with abnormal mitochondrial reorganisation and dysfunction and, thus, with the onset of oxidative stress (Lord et al. 2013). Indeed, excessive reactive oxygen species (ROS) induce cell cycle arrest and oocyte damage via apoptosis in CCs (Torner et al. 2004). Therefore, excess of ROS contribute to the reduced developmental competence in oocytes from humans (Wilding et al. 2001; for a review, see Van Blerkom 2011), mice (Thouas et al. 2004) and bovine (Stojkovic et al. 2001).

Taking into account these premises, the first aim of the present study was to compare the gene expression of Gjal and Ptgs 2 mRNA in CCs from in vivo-matured oocytes (with presumably higher developmental competence) compared with
IVM and immature oocytes (with potentially lower developmental competence). In addition, we analysed the expression of other putative transcripts involved in cell cycle and viability (V-Akt murine thymoma viral oncogene homologue 1 (Akt1)), cell cycle regulation and apoptosis (tumour protein 53 (Tp53), caspase 3, apoptosis-related cysteine protease (Casp3)), oxidative response (superoxide dismutase 2, mitochondrial (Sod2)) and metabolism (glucose-6-phosphate dehydrogenase ( $G 6 p d$ ), glyceraldehyde-3-phosphate dehydrogenase (Gapdh)) in germinal vesicle $(\mathrm{GV})$ immature, in vivo-matured and IVM oocytes and their CCs to identify potential target genes related to differences in the developmental competence of oocytes. Meiotic progression, cytoplasmic maturation (based on establishment of mitochondrial distribution patterns), early embryo development after IVF and the apoptotic rate in CCs were assessed to corroborate the genetic pool related to oocyte quality of rabbit COCs.

\section{Materials and methods}

Unless stated otherwise, all chemicals were purchased from Sigma Chemical.

\section{Oocyte collection and IVM}

Immature oocytes for IVM were recovered from adult New Zealand $\times$ California white rabbit does (Oryctolagus cuniculus; $n=30$ ) located in the facilities of the Polytechnic University of Madrid. Ovaries were obtained by mid-ventral laparotomy of does after they had been sedated with $35 \mathrm{mg} \mathrm{kg}^{-1}$ ketamine (Imalgene 1000; Merial) and killed using an intravenous bolus of barbiturate $\left(30 \mathrm{mg} \mathrm{kg}^{-1}\right.$; Dolethal; Vetoquinol). The procedures were performed in accordance with the policies of the University Scientific Ethics Committee and the Spanish Policy for Animal Protection (RD53/2013), which meets the European Union Directive about the protection of animals used in experimentation.

Then, ovaries were placed in phosphate-buffered saline (PBS) at $37^{\circ} \mathrm{C}$ and transported to the laboratory. Ovarian follicles $\geq 1 \mathrm{~mm}$ in diameter were aspirated with a 2-mL syringe and 23-g needle under a stereoscopic microscope (Nikon). COCs with a compact cumulus were washed with PBS supplemented with $1 \mathrm{mg} \mathrm{mL}^{-1}$ polyvinylpolypyrrolidone (PVP) and selected on the basis of the morphological appearance of the $\mathrm{CCs}$ and cytoplasmic homogeneity. Immature COCs were processed for quantification of mRNA transcripts and for investigation of mitochondrial distribution. IVM COCs were obtained after culture for $16 \mathrm{~h}$ at $38^{\circ} \mathrm{C}$ under an atmosphere of $5 \% \mathrm{CO}_{2}$ in air with maximum humidity. The maturation medium consisted of tissue culture media (TCM)-199 with $2 \mathrm{mM}$ L-glutamine, $0.1 \mathrm{mg} \mathrm{mL}^{-1}$ sodium pyruvate, $0.3 \%$ bovine serum albumin (BSA) and $10 \mathrm{ng} \mathrm{mL}^{-1}$ epidermal growth factor (EGF), as reported previously (Lorenzo et al. 1996).

To obtain in vivo-matured COCs, 27 does were killed, as described above, $15 \mathrm{~h}$ after the induction of ovulation. Ovulation was induced by intramuscular injection of gonadorelin, a synthetic analogue of gonadotrophin-releasing hormone $(20 \mu \mathrm{g}$, i.m.; Inducel-GnRH; Ovejero). Ovulated oocytes were recovered by flushing the reproductive tract with PBS supplemented with $1 \mathrm{mg} \mathrm{mL}^{-1}$ PVP. 
Table 1. Primers used for amplification of genes of interest from rabbit oocytes and cumulus cells using quantitative reverse transcriptionpolymerase chain reaction

H2afz, Histone family member z; Gjal, gap junction protein, alpha 1, $43 \mathrm{kDa}$; Ptgs 2, prostaglandin-endoperoxide synthase 2; Akt1, V-Akt murine thymoma viral oncogene homologue 1; Tp53, tumour protein 53; Casp3, caspase 3, apoptosis-related cysteine protease; Sod2, superoxide dismutase 2, mitochondrial; G6pd, glucose-6-phosphate dehydrogenase; Gapdh, glyceraldehyde-3-phosphate dehydrogenase

\begin{tabular}{|c|c|c|c|}
\hline Gene & Primer sequence $\left(5^{\prime}-3^{\prime}\right)$ & Fragment size (bp) & GenBank Accession no. \\
\hline$H 2 a f z$ & $\begin{array}{l}\text { Forward: AGGACGACTAGCCATGGACGTGTG } \\
\text { Reverse: CCACCACCAGCAATTGTAGCCTTG }\end{array}$ & 212 & NM_016750 \\
\hline Gjal & $\begin{array}{l}\text { Forward: TGCCTTTCGTTGTAACACTCA } \\
\text { Reverse: AGAACACATGAGCCAAGTACA }\end{array}$ & 142 & NM_001198948.1 \\
\hline Ptgs 2 & $\begin{array}{l}\text { Forward: TCCAAGCTGGCCTCACTGATGG } \\
\text { Reverse: AGCATGTGTGTGGCCCGACTTG }\end{array}$ & 169 & NM_001082388.1 \\
\hline Akt1 & $\begin{array}{l}\text { Forward: CACCACTGGATTTCTCTGCCT } \\
\text { Reverse: GGTACCGTTTGTTGACTGTGC }\end{array}$ & 230 & XM_008257300.1 \\
\hline Tp53 & $\begin{array}{l}\text { Forward: GTGCTGACCAGGGACACGGC } \\
\text { Reverse: CTGCACCAGGGCAGACCAGC }\end{array}$ & 223 & NM_001082404.1 \\
\hline Casp3 & $\begin{array}{l}\text { Forward: ACCCAGAAGACTGTGGATGG } \\
\text { Reverse: AYGCCTGCTTCACCACCTTC }\end{array}$ & 247 & BC102589 \\
\hline Sod2 & $\begin{array}{l}\text { Forward: GCTTACAGATTGCTGCTTGT } \\
\text { Reverse: AAGGTAATAAGCATGCTCCC }\end{array}$ & 101 & S67818.1 \\
\hline G6pd & $\begin{array}{l}\text { Forward: CTGATCCTGGGTCGCTTCAT } \\
\text { Reverse: ACGTACATGGGCACAAAACCA }\end{array}$ & 68 & NM_174602.2 \\
\hline Gapdh & $\begin{array}{l}\text { Forward: CGCTGGGACGGGGTGCCCTTCATC } \\
\text { Reverse: CGCCAGGCCTCCCGCAGTTCATCA }\end{array}$ & 347 & XM_583628.4 \\
\hline
\end{tabular}

\section{RNA extraction and reverse transcription in COCS}

In all, 132 COCs were used for mRNA abundance analysis ( $n=45,45$ and 42 immature, IVM and in vivo-matured COCs respectively). CCs were mechanically removed by gentle repeated pipetting in PBS $+1 \mathrm{mg} \mathrm{mL}^{-1}$ PVP medium. Groups of 10-12 oocytes and their corresponding CCs were analysed separately. Oocytes and CCs were placed in different $1.5-\mathrm{mL}$ Eppendorf tubes, snap frozen in liquid nitrogen and stored at $-80^{\circ} \mathrm{C}$ until analysis. Poly(A) RNA was prepared as described previously (Bermejo-Álvarez et al. 2010; Arias-Alvarez et al. 2013a) using the Dynabeads mRNA Direct Extraction KIT (Dynal Biotech) according to the manufacturer's instructions with minor modifications. The reverse transcription (RT) reaction (Bioline) was performed using poly $(\mathrm{T})$ primer, random primers and Moloney murine leukaemia virus reverse transcriptase enzyme (MMLV High-performance Reverse Transcriptase; Epicentre Biotechnologies) in a total volume of $40 \mu \mathrm{L}$ to produce cDNA. First, tubes were heated at $70^{\circ} \mathrm{C}$ for $5 \mathrm{~min}$ to denature the secondary RNA structure and then the RT was completed with the addition of 100 units Superscript RT enzyme MMLV. The samples were subsequently incubated at $42^{\circ} \mathrm{C}$ for 60 min to allow RT of RNA, followed by incubation at $70^{\circ} \mathrm{C}$ for 10 min to denature the RT enzyme.

\section{Quantitative real-time polymerase chain reaction in COCs}

The mRNA transcripts were quantified using real-time quantitative RT-polymerase chain reaction (qRT-PCR). Experiments were conducted to determine levels of each transcript relative to that of the housekeeping gene H2afz (Histone family member z).
All primers were designed using Primer-BLAST software (www.ncbi.nlm.nih.gov/tools/primersblast/) to span exon-exon boundaries when possible. All qPCR reactions were performed in duplicate using a Rotorgene 6000 RealTime Cycler (Corbett Research) after addition of $2 \mu \mathrm{L}$ sample to the PCR mix (GoTaq qPCR Master Mix; Promega) containing specific primers to amplify the housekeeping gene, Akt1, Tp 53, Casp3, Sod2, G6pd and Gapdh. Gjal and Ptgs 2 were quantified only in CCs because their expression is related to cell-cell communication and cumulus expansion. According to Feuerstein et al. (2007) and Shao et al. (2015), the quantification of such genes can be used as a method to evaluate the quality of granulosa cells and indirectly as a biomarker of oocyte quality. Primer sequences and the approximate size of the amplified fragments for all transcripts are given in Table 1. Cycling conditions were $94^{\circ} \mathrm{C}$ for $3 \mathrm{~min}$, followed by 35 cycles of $94^{\circ} \mathrm{C}$ for $15 \mathrm{~s}, 56^{\circ} \mathrm{C}$ for $30 \mathrm{~s}$, $72^{\circ} \mathrm{C}$ for $10 \mathrm{~s}$ and $10 \mathrm{~s}$ of fluorescence acquisition. Each pair of primers was optimised to achieve efficiencies close to 1 , and the comparative cycle threshold $\left(\mathrm{C}_{\mathrm{T}}\right)$ method was then used to quantify expression levels as described by Schmittgen and Livak (2008). To avoid primer dimer artefacts, fluorescence was acquired in each cycle at a temperature higher than the melting temperature of primer dimers (specific for each product; $\left.76-86^{\circ} \mathrm{C}\right)$. Then, the threshold cycle or the cycle during the loglinear phase of the reaction at which fluorescence increased above background was determined for each sample. Quantification was normalised against that of the endogenous control $H 2 a f z$. According to the comparative $\mathrm{C}_{\mathrm{T}}$ method, the $\Delta \mathrm{C}_{\mathrm{T}}$ value was determined by subtracting the $H 2 a f z \mathrm{C}_{\mathrm{T}}$ value for each sample from each gene $\mathrm{C}_{\mathrm{T}}$ value of the sample. Calculation of ${ }^{\Delta \Delta} \mathrm{C}_{\mathrm{T}}$ involved using the highest sample $\Delta \mathrm{C}_{\mathrm{T}}$ value as an 
arbitrary constant to subtract from all other $\Delta \mathrm{C}_{\mathrm{T}}$ sample values. Fold changes in the relative gene expression of the target were determined using the formula $2^{-\Delta \Delta C T}$.

\section{Confocal laser scanning microscopy in COCs Mitochondrial staining}

In all, 66 oocytes were prepared to observe the active mitochondrial migration pattern before $(n=20)$ and after $(n=46)$ the IVM period. In addition, 27 in vivo-matured oocytes were used to verify the mitochondrial migration pattern.

For all oocytes, CCs were mechanically removed by gentle repeated pipetting in PBS $+1 \mathrm{mg} \mathrm{mL}^{-1}$ PVP. Then, denuded oocytes were washed with PBS and incubated with $200 \mu \mathrm{M}$ MitoTracker Orange probes (Invitrogen) at $38^{\circ} \mathrm{C}$ for $30 \mathrm{~min}$. The MitoTracker Orange probe passively diffuses across the plasma membrane and enters live cells, where it is oxidised to the corresponding fluorescent mitochondrion-selective probe and accumulated in active mitochondria. After incubation, oocytes were fixed using $4 \%$ paraformaldehyde solution and washed with PBS. The oocytes were then stained with $1 \mu \mathrm{g} \mathrm{mL}^{-1}$ Hoechst 33342 dye to assess nuclear morphology related to oocyte maturation. Finally, oocytes were mounted on glass slides and observed under a laser scanning confocal microscope (Leica TCS SP2), using 546- and 351/364-nm excitation lasers to visualise mitochondria and chromosomes respectively. The format, laser, gain and offset were kept constant for every sample. The mitochondrial migration pattern was observed and classified at $\times 40$ magnification under mineral oil. Nuclear morphology was categorised as GV, MI and MII.

\section{Cumulus cell apoptosis assessed by terminal deoxyribonucleotidyl transferase-mediated dUTP-digoxigenin nick end-labelling}

To evaluate apoptosis in CCs, 37 COCs $(n=14,13$ and 10 from immature, IVM and in vivo-matured oocytes respectively) were used. COCs were washed in PBS supplemented with $1 \mathrm{mg} \mathrm{mL}^{-1}$ PVP and fixed in 4\% paraformaldehyde solution for $1 \mathrm{~h}$ at room temperature. The COCs were pretreated with $20 \mathrm{mg} \mathrm{mL}^{-1}$ proteinase $\mathrm{K}$ working solution for $1 \mathrm{~h}$ in a humidified dark chamber at $37^{\circ} \mathrm{C}$. Strand breaks of DNA occurring during the cell apoptosis process were detected using terminal deoxyribonucleotidyl transferase-mediated dUTP-digoxigenin nick end-labelling (TUNEL; In Situ Cell Death Detection Kit, POD; Roche Diagnostics) with a protocol adapted from Arias-Álvarez et al. (2009). Positive control sections were treated with DNAse I (Roche Diagnostics) for $10 \mathrm{~min}$ at room temperature in a humidified chamber before incubation with the TUNEL reaction. As a negative control, samples were incubated with the label solution of the TUNEL reaction mixture without the enzymatic solution. To avoid RNA interference, COCs were treated with RNAses before staining. Finally COCs were counterstained with $0.25 \mu \mathrm{g} \mathrm{mL}^{-1}$ propidium iodide for $15 \mathrm{~min}$ and mounted between a coverslip and glass slide in mounting solution (ProLong Gold Antifade Reagent; Invitrogen). Samples were observed under a laser scanning confocal microscope (Leica TCS SP2) using a 488-nm excitation laser to visualise TUNEL-positive cells and a 546-nm excitation laser to assess red fluorescence. The format, laser, gain and offset were kept constant for all samples. Images were analysed using ImageJ software (http://rsbweb.nih.gov/ij/). The apoptosis index was calculated as the green area divided by the red area $\times 100$.

\section{Assessment of the developmental competence of oocytes}

The developmental competence of oocyte was evaluated by IVF and in vitro culture (IVC) procedures as described previously (Zeng et al. 1999; Viudes-de-Castro et al. 2005) with some modifications described below. In all, 350 IVM and in vivomatured oocytes were used in two replicates.

IVF was performed using a pool of heterospermic fresh semen collected using an artificial vagina from five adult bucks. The motility of ejaculated spermatozoa was $>85 \%$. The sperm samples were diluted 1:50 in fertilisation medium (Tyrode's medium with sodium bicarbonate $(2 \mathrm{mM})$, sodium lactate $(36 \mathrm{mM})$, sodium pyruvate $(1 \mathrm{mM}), 0.01 \%$ BSA and heparin $\left.\left(10 \mu \mathrm{g} \mathrm{mL}^{-1}\right)\right)$, washed with fertilisation medium and centrifuged twice at $1000 \mathrm{~g}$ for $5 \mathrm{~min}$ at room temperature each time. The spermatozoa were then subjected to a swim-up procedure in $2 \mathrm{~mL}$ Tyrode's medium for $20 \mathrm{~min}$ under an atmosphere of $5 \% \mathrm{CO}_{2}$ in air with maximum humidity at $38^{\circ} \mathrm{C}$. The spermatozoa recovered from the supernatant were incubated for a further $6 \mathrm{~h}$ under the same conditions. Then, IVM and in vivo-matured oocytes were coincubated with spermatozoa at a final concentration of $1 \times 10^{6}$ spermatozoa $\mathrm{mL}^{-1}$ for $4 \mathrm{~h}$ at $38^{\circ} \mathrm{C}$ in four-well dishes containing $50 \mathrm{COCs}$ in $500 \mathrm{~mL}$ Tyrode's medium per well.

After the coincubation, presumptive zygotes were denuded by gentle pipetting, washed four times in PBS and cultured in TCM-199 supplemented with 20\% (v/v) fetal calf serum (FCS), as described previously (Arias-Álvarez et al. 2010). Then, groups of 25 zygotes were placed in $25-\mu \mathrm{L}$ droplets of culture medium overlaid with mineral oil and incubated for $60 \mathrm{~h}$ under an atmosphere of $5 \% \mathrm{CO}_{2}$ in air with maximum humidity at $38.5^{\circ} \mathrm{C}$. Differences in oocyte developmental competence between in vivo-matured and IVM oocytes were scored according to embryo development at 12,36 and $60 \mathrm{~h}$ post-insemination (hpi). Embryos were classified on the basis of conventional morphological criteria according to their developmental stage following the guidelines of the International Embryo Transfer Society (www.iets.org). The number of 2- to 4-cell embryos, 8 - to 16 -cell embryos, early morulae, morulae and early blastocysts was expressed as a percentage of the total number of presumptive zygotes.

\section{Statistical analysis}

Data were analysed using SPSS Version 19 (IBM SPSS Statistics). The Shapiro-Wilks test was used to assess normality and homogeneity of variance. Comparisons of the apoptosis rate and mRNA transcript expression between groups were made using one-way analysis of variance (ANOVA) followed by Bonferroni's post hoc test or a Kruskal-Wallis test for non-parametric samples. Nuclear maturation categories, mitochondrial patterns and in vitro early embryo development were compared using a Chi-squared test. All data are expressed as the mean \pm s.e.m. and two-tailed $P<0.05$ was considered significant. 


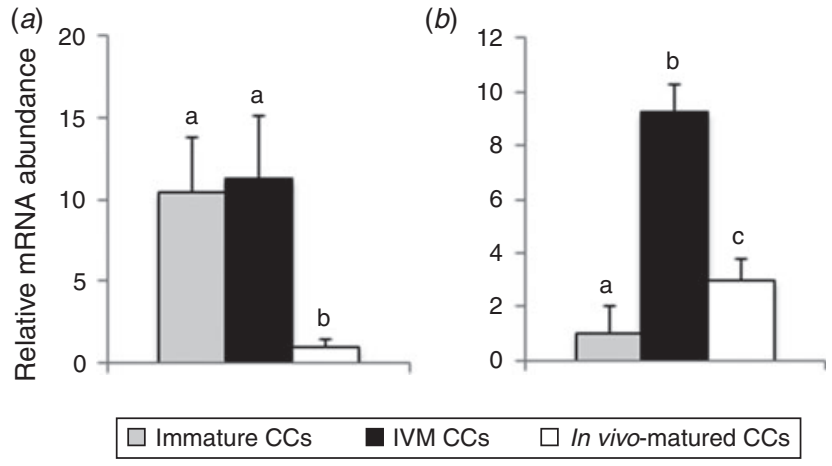

Fig. 1. Relative mRNA abundance of (a) gap junction protein, alpha 1, 43 $\mathrm{kDa}($ Gjal) and (b) prostaglandin-endoperoxide synthase 2 (Ptgs2) in cumulus cells (CCs) of germinal vesicle (immature), IVM and in vivomatured oocytes. Data are the mean \pm s.e.m. Columns with different letters differ significantly $(P<0.05)$.

(a)
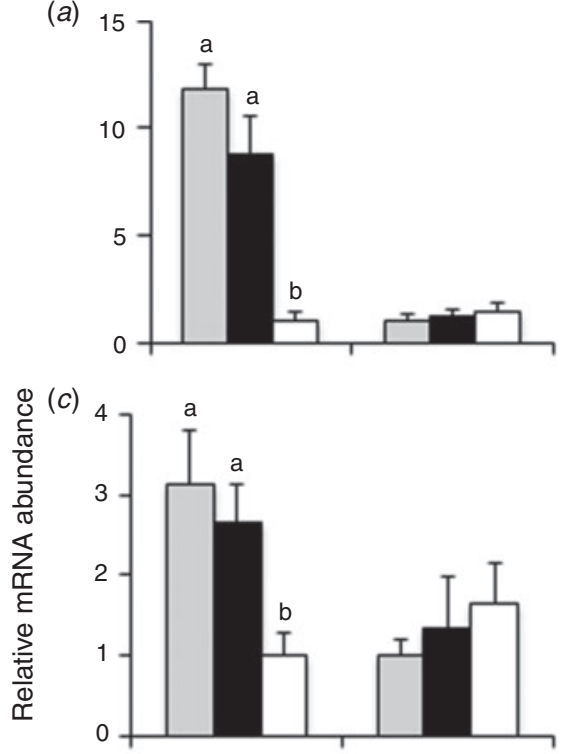

(e)

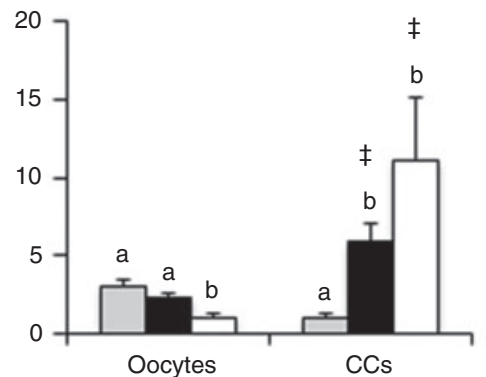

\section{Results}

Transcript abundance of quality-related genes in COCs

The relative abundance of genes related to cumulus expansion, namely Gjal and Ptgs 2, in CCs is shown in Fig. 1. No significant differences were observed in the abundance of Gjal transcripts before and after IVM. However, Gjal expression was significantly lower in CCs from in vivo-matured oocytes (Fig. 1a; $P<0.05)$. Transcripts of Ptgs 2 were upregulated after in vitro and in vivo oocyte maturation $(P<0.05)$; nevertheless, Ptgs 2 mRNA expression was significantly higher in CCs from COCs matured in vitro than from those matured in vivo (Fig. 1b; $P<0.05)$.

The expression of the other transcripts evaluated in both oocytes and CCs are shown in Fig. 2. In oocytes, Akt, Tp53, Casp3, Sod2 and G6pd poly(A) mRNA content was significantly downregulated after in vivo maturation compared with IVM and GV (immature) oocytes $(P<0.05)$. Only Sod 2

(b)

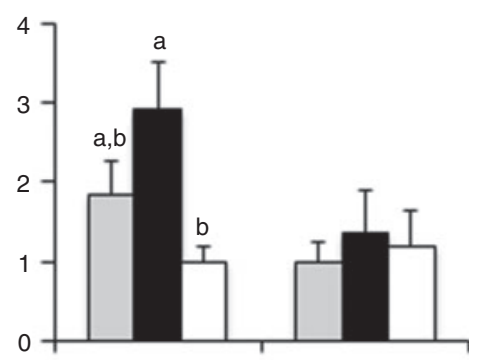

(d)

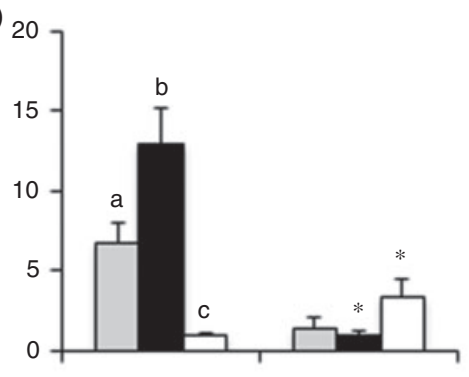

(f)

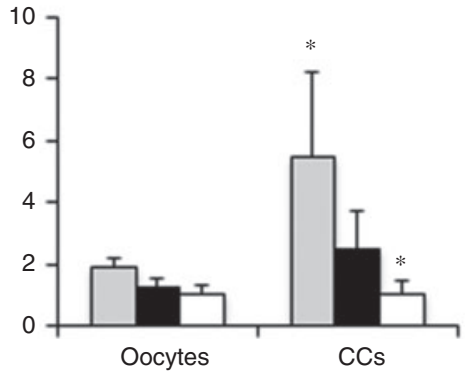

Immature

- IVM

$\square$ In vivo matured

Fig. 2. Relative mRNA abundance of genes in immature, IVM and in vivo-matured oocytes and cumulus cells (CCs). (a) V-Akt murine thymoma viral oncogene homologue 1 (Akt1), (b) tumour protein 53 (Tp53), (c) caspase 3, apoptosis-related cysteine protease (Casp3), (d) superoxide dismutase 2, mitochondrial (Sod2), (e) glucose-6-phosphate dehydrogenase $(G 6 p d)$ and $(f)$ glyceraldehyde-3-phosphate dehydrogenase $(G a p d h)$. Data are the mean \pm s.e.m. Columns with different letters differ significantly. Data with * differs $(P=0.06)$ and ${ }^{\ddagger}$ differs $(P=0.1)$. 
poly(A) mRNA content was significantly increased in oocytes after IVM compared with GV stage oocytes $(P<0.05)$. However, no differences in the gene expression of Akt, Tp53 and Casp3 were found in CCs among the experimental groups. Although Sod2 expression tended to be upregulated in CCs from in vivo-matured COCs compared with IVM COCs $(P=0.06), \operatorname{Sod} 2$ mRNA expression was similar before and after oocyte maturation. G6pd transcripts were upregulated after oocyte maturation in CCs $(P<0.05)$ and tended to be higher after in vivo maturation $(P=0.1)$. The mRNA abundance of Gapdh tended to be lower in CCs from in vivo-matured COCs compared with immature COCs $(P=0.06)$, with values in IVM CCs being intermediate between these two groups.

\section{Oocyte maturation and mitochondrial distribution patterns}

As shown in Fig. 3, the mitochondrial migration pattern found was classified as either: (1) diffused homogeneous (DH), with fluorescence dispersed throughout the entire cytoplasm; (2) diffused clustered (DC), with aggregates of fluorescence dispersed throughout the cytoplasm; (3) migrated homogeneous $(\mathrm{MH})$, with high fluorescence in the cortical area and moderate through the cytoplasm; and (4) migrated clustered (MC), with higher fluorescence in cortical areas with aggregates. Before IVM, $100 \%$ of oocytes exhibited GV nuclear morphology. After IVM, $63 \%$ of oocytes were at the MII stage $(n=29), 28.3 \%$ were at the MI stage $(n=13)$ and $8.7 \%$ were at the GV stage $(n=4)$. All in vivo-matured oocytes exhibited the MII configuration.

Fig. 4 shows that the immature oocytes mainly exhibited a DH mitochondrial distribution $(P<0.001)$, whereas the most prevalent mitochondrial pattern in in vivo-matured oocytes was the MH pattern $(P<0.001)$. In the IVM group, the mitochondrial migration pattern most frequently observed was $\mathrm{MC}$ rather than $\mathrm{MH}(P<0.05)$. The rest of mitochondrial patterns defined in this group (DH, DC) showed intermediate values. Comparing experimental groups, $\mathrm{MH}$ distribution was significantly higher in in vivo-matured MII oocytes than in IVM or GV (immature) oocytes $(P<0.001)$. The MC pattern was significantly more frequent in IVM oocytes than in the other experimental groups $(P<0.05)$. The DC pattern was also more frequent in IVM than in vivo-matured oocytes $(P<0.05)$, with immature oocytes having intermediate values. The percentage of oocytes with the DH pattern of mitochondrial distribution increased significantly in the immature oocyte group compared with the in vivomatured group $(P<0.001)$. After IVM, oocytes tended to have
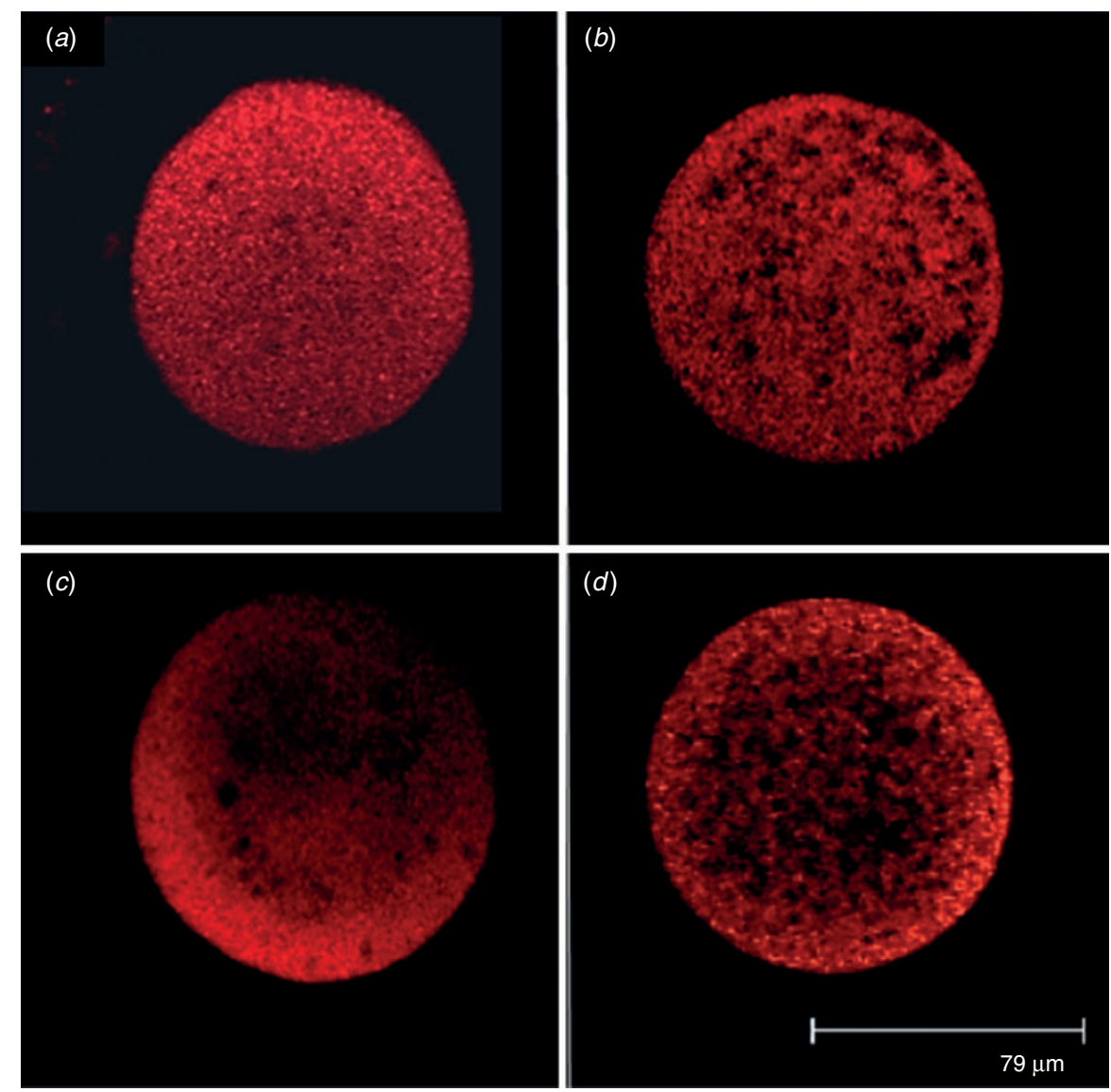

Fig. 3. Mitochondrial relocation in rabbit oocytes. Mitochondrial migration patterns were classified as (a) diffused homogeneous, (b) diffused clustered, $(c)$ migrated homogeneous or $(d)$ migrated clustered (MC). 


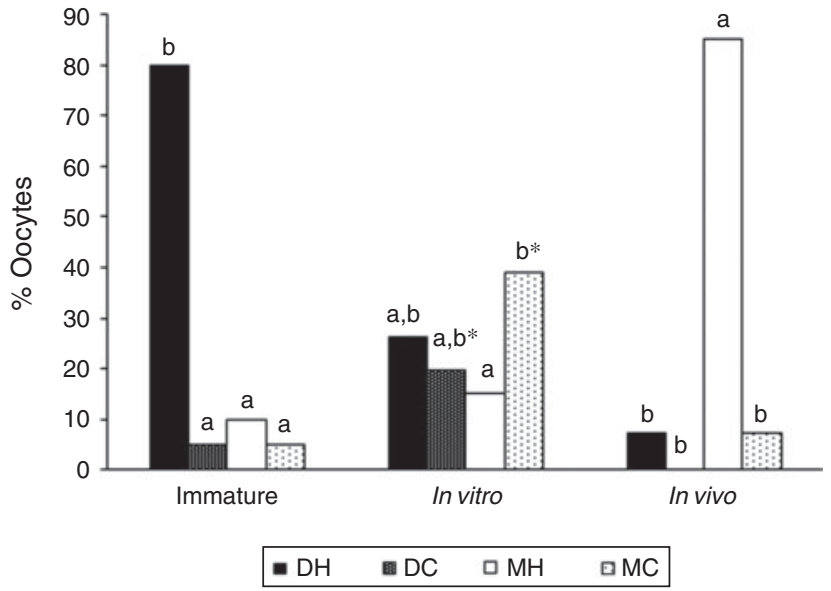

Fig. 4. Percentage of germinal vesicle (immature), IVM and in vivomatured oocytes exhibiting the different mitochondrial distribution patterns. Data are the mean \pm s.e.m. Within each group, columns with different letters differ significantly. Data with $*$ differs $(P=0.1)$. DH, diffused homogeneous; DC, diffused clustered; $\mathrm{MH}$, migrated homogeneous; $\mathrm{MC}$, migrated clustered. higher values of the $\mathrm{DH}$ pattern than in vivo-matured oocytes $(P=0.1)$, but there was no significant difference between the IVM and immature groups.

\section{Apoptosis of CCs}

The percentage of apoptosis was significantly lower in COCs matured in vivo compared with those matured in vitro or the immature group $(6.0 \pm 1.0 \%$ vs $10.9 \pm 1.7 \%$ and $11.0 \pm 2.0 \%$ respectively; $P<0.05$; Fig. 5). The rate of apoptosis was similar in CCs from immature and IVM oocytes.

\section{Developmental competence of oocytes}

Cumulus expansion just before coincubation with spermatozoa is shown in Fig. 6. Morphological differences can be seen between IVM and in vivo-matured groups. Ovulated oocytes seem to have a better pattern of CC expansion.

As indicated in Table 2, the kinetics of early embryo development were affected by the origin of the embryos (in vitro or in vivo). The cleavage rate after IVF increased significantly $(P<0.01)$ in embryos derived from ovulated oocytes compared with those derived from IVM oocytes.
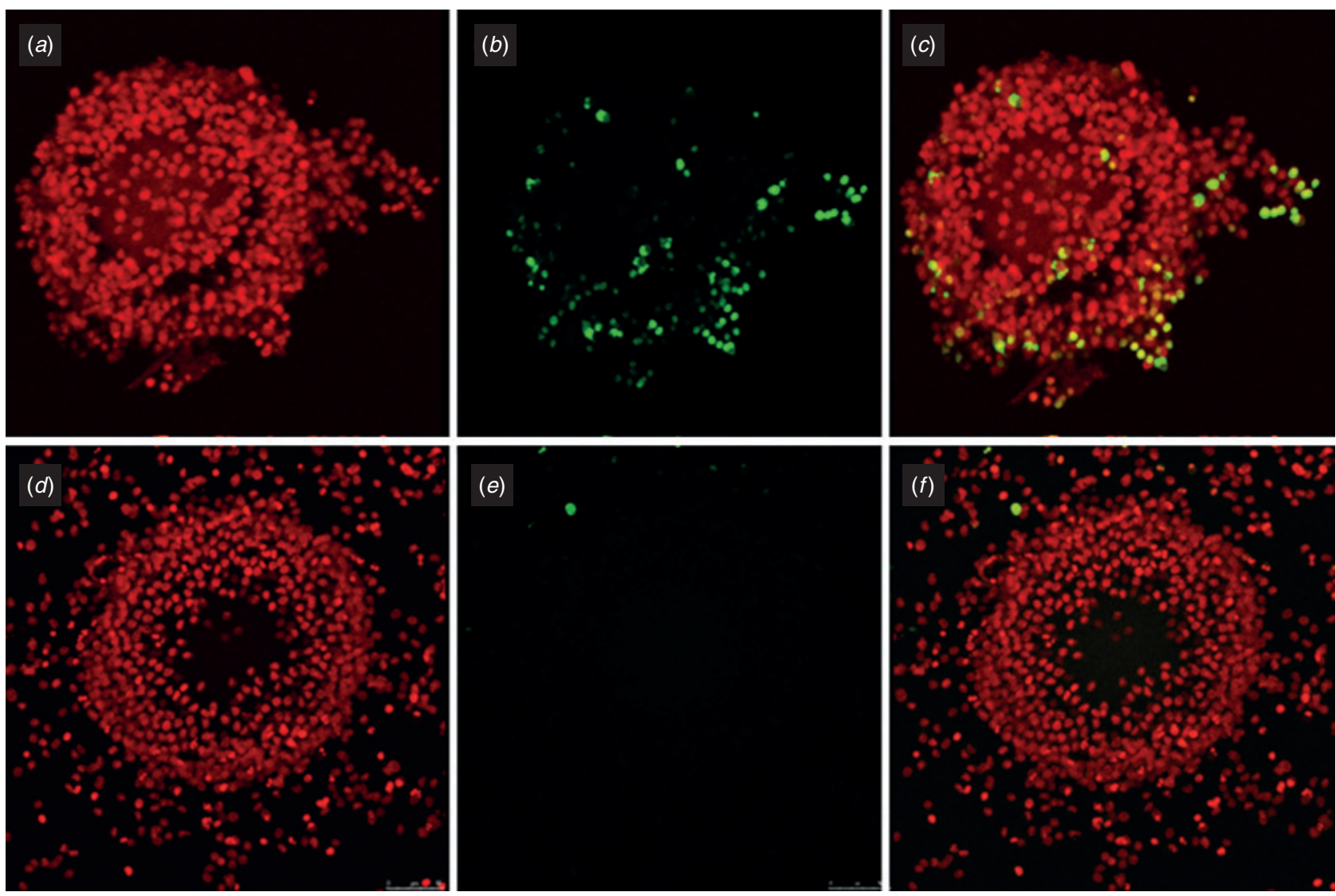

Fig. 5. Cumulus cell apoptosis assessed by the terminal deoxyribonucleotidyl transferase-mediated dUTP-digoxigenin nick end-labelling (TUNEL) assay in rabbit cumulus-oocyte complexes (COCs) after $(a-c)$ IVM and $(d-f)$ in vivo maturation. $(a, d)$ Maximal projection of a complete COC showing the nuclei of cumulus cells stained with propidium iodide (red). $(b, e)$ Maximal projection of a complete COC showing TUNEL-positive cells considered as apoptotic (green). $(c, f)$ Maximal projection of a complete COC overlapping both fluorochromes. Images were taken at an original magnification of $\times 40$. 

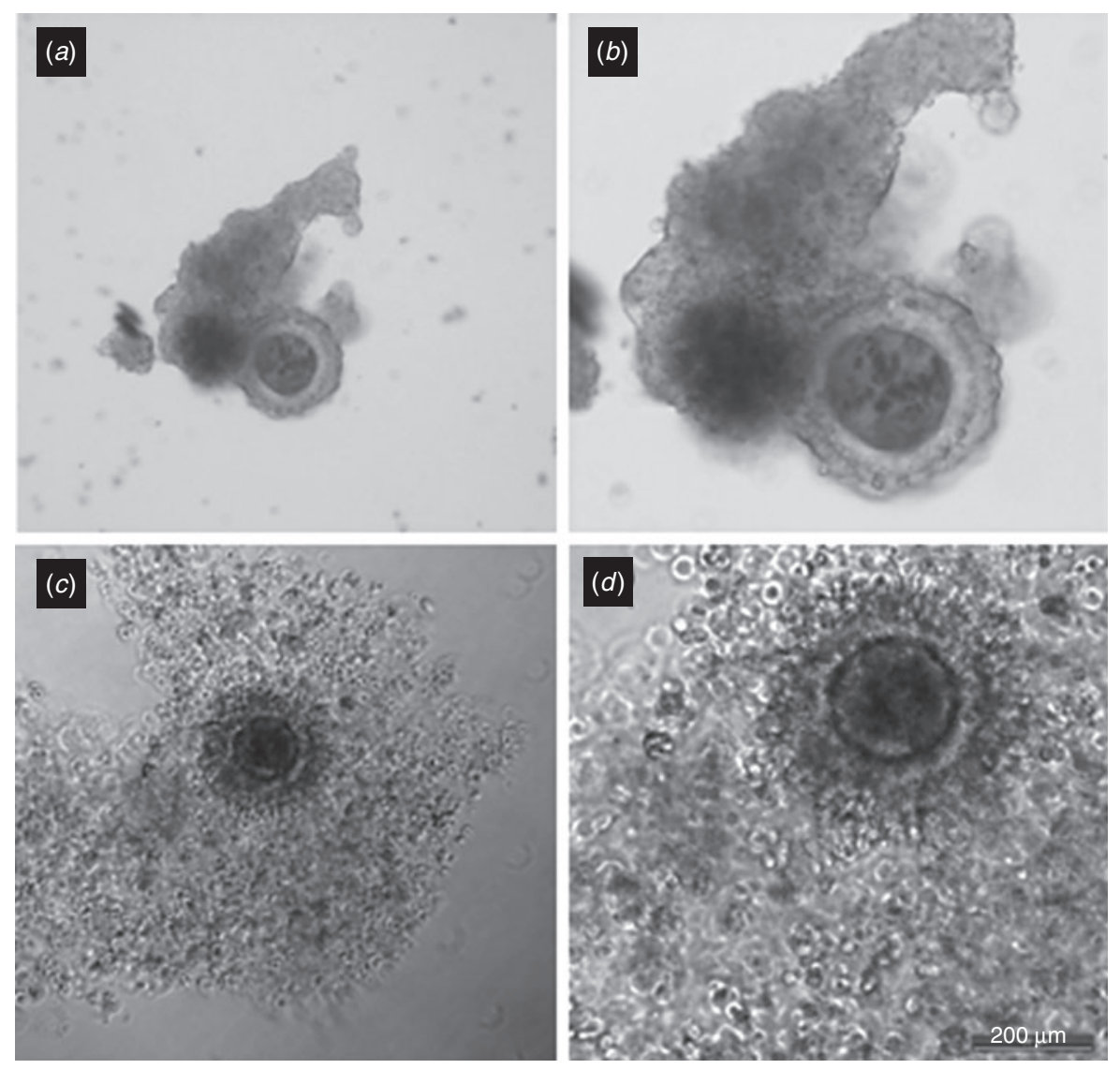

Fig. 6. Cumulus-oocyte complexes after $(a, b)$ IVM or $(c, d)$ in vivo maturation. Scale bar $=200 \mu \mathrm{m}$.

Table 2. Early development of rabbit embryos derived from in vivo-matured and IVM oocytes

Within columns, values with different letters differ significantly $(P<0.01)$. Values with $*$ differ $(P=0.08)$

\begin{tabular}{|c|c|c|c|c|c|c|c|c|c|c|}
\hline \multirow{2}{*}{\multicolumn{2}{|c|}{ Presumptive zygotes }} & \multirow{2}{*}{$\begin{array}{c}\text { Total } \\
\text { cleaved }\end{array}$} & \multirow{2}{*}{$\begin{array}{c}12 \mathrm{~h} \\
\text { 2- to 4-cells }\end{array}$} & \multicolumn{3}{|c|}{$36 \mathrm{~h}$} & \multicolumn{4}{|c|}{$60 \mathrm{~h}$} \\
\hline & & & & 2- to 4-cells & 8- to 16 -cells & $\begin{array}{c}\text { Early } \\
\text { morulae }\end{array}$ & 2- to 4-cells & 8- to 16 -cells & Morulae & $\begin{array}{c}\text { Early } \\
\text { blastocysts }\end{array}$ \\
\hline \multicolumn{11}{|c|}{ In vitro-derived oocytes } \\
\hline$n$ & 184 & $44^{\mathrm{a}}$ & $33^{\mathrm{a}}$ & $39 *$ & $5^{\mathrm{a}}$ & $0^{\mathrm{a}}$ & 36 & $1^{\mathrm{a}}$ & $6^{\mathrm{a}}$ & 1 \\
\hline$\%$ & & 23.9 & 17.9 & 21.2 & 2.7 & 0.0 & 19.5 & 0.5 & 3.3 & 0.5 \\
\hline \multicolumn{11}{|c|}{ In vivo-recovered oocytes } \\
\hline$n$ & 160 & $79^{\mathrm{b}}$ & $47^{\mathrm{b}}$ & $47 *$ & $26^{\mathrm{b}}$ & $6^{\mathrm{b}}$ & 35 & $22^{\mathrm{b}}$ & $15^{\mathrm{b}}$ & 2 \\
\hline$\%$ & & 49.3 & 29.4 & 29.4 & 16.2 & 3.7 & 21.8 & 13.8 & 9.4 & 1.3 \\
\hline
\end{tabular}

The percentage of 2- to 4-cell embryos at 12 hpi was significantly higher in the group of in vivo-derived oocytes compared with the in vitro group $(P<0.01)$. Similarly, the percentage of all categorised embryos at 36 and at $60 \mathrm{hpi}$ was significantly greater in the group derived from in vivo-matured compared with IVM oocytes $(P<0.01)$, except for the early blastocyst rate.

\section{Discussion}

In vivo-matured COCs seem to be an adequate model in which to identify biomarkers to evaluate the developmental competence of oocytes and to understand the molecular mechanisms underlying the communication between oocytes and CCs. The findings of the present study corroborate that the gene expression profile of in vivo-matured rabbit COCs is different from that of IVM COCs. These changes in gene expression are clearly accompanied by stage-specific cytoplasmic remodelling of mitochondria, a lower rate of apoptosis of in vivo-matured CCs and better early embryo development, indicating that oocyte quality is compromised during IVM.

Cumulus expansion is positively linked to oocyte quality, which is widely used to evaluate the maturity of COCs. GJA1, or 
connexin 43 , has been proposed as a major mediator of cell-cell communication via gap junctions (Gittens and Kidder 2005) and has been identified as a non-invasive biomarker for the fertilisation potential of human oocytes (Feuerstein et al. 2007; Hasegawa et al. 2007). The findings of the present study show that Gjal expression was significantly lower CCs surrounding in vivo-matured MII oocytes than in CCs enclosing immature or IVM oocytes, supporting previous results obtained in the bovine (Calder et al. 2003), canine (Cho et al. 2016) and in humans (Li et al. 2015). The reduced expression of GJA1 in CCs after oocyte maturation is beneficial (Edry et al. 2006) because it is related to cumulus expansion and decreased diffusion of cAMP and cGMP from the CCs to the oocyte, which is followed by the end of meiotic arrest and extrusion of the first polar body (Shao et al. 2015).

Conversely, PTGS2 is the key enzyme in prostaglandin E biosynthesis and is also involved in regulation of CC expansion during the ovulatory process in mice (Davis et al. 1999; Jang et al. 2015). In the present study, Ptgs 2 mRNA transcripts were upregulated in CCs after oocyte maturation, as described previously for cattle (Nuttinck et al. 2002), mice (Shao et al. 2015) and humans (Feuerstein et al. 2007; Wathlet et al. 2011). The abundance of PTGS2 in CCs is positively correlated with oocyte competence in other species, including cattle (Assidi et al. 2008), pigs (Kang et al. 2012) and humans (McKenzie et al. 2004). However, in the present work, Ptgs 2 mRNA expression was significantly lower in CCs from in vivo-matured rabbit COCs, which exhibited better CC expansion and higher developmental competence after IVF. In contrast with these results, previous reports in the bovine (Tesfaye et al. 2009) and humans (Ouandaogo et al. 2012) have found that PTGS2 is lower in CCs from oocytes matured in vitro compared with those matured in vivo. The reason for this discrepancy could be associated with the ovarian stimulation protocols used, which could interfere in the endocrine and cytokine environment and induce changes in the gene expression in $\mathrm{CCs}$, as reported previously in mice (Foster et al. 2010), rats (Agca et al. 2013) and women (Smitz et al. 2007; Adriaenssens et al. 2010; Wathlet et al. 2011). In fact, PTGS2 mRNA decreases after human chorionic gonadotrophin administration in equine granulosa cells (Boerboom and Sirois 1998). Taking these observations into account, the present study cannot confirm Ptgs 2 as a candidate biomarker of oocyte competence in the rabbit.

Although in rabbits the chromosomes are tightly condensed in oocytes enclosed in antral follicles $\geq 1 \mathrm{~mm}$ in diameter (Jelíanková et al. 1994), RNA transcription is still active and the oocyte fully meiotic competent (Wang et al. 2009). During meiotic maturation, a global decrease in transcription levels of the accumulated maternal mRNA is expected (Bachvarova 1985; Kohata et al. 2013), because translated transcripts undergo deadenylation and selective degradation (Paynton and Bachvarova 1994). In the present study, most of the mRNA transcripts associated with cell cycle checkpoint, apoptosis and metabolic pathways were downregulated in in vivo-matured MII oocytes compared with immature GV and IVM oocytes. Dysregulation in either gene transcription or post-transcriptional modification of genes in IVM oocytes would result in incorrect temporal utilisation of those transcripts, which may culminate in reduced developmental competence (Zheng et al. 2005a; Jones et al. 2008). The serine/threonine kinase Akt contributes to the regulation of the meiotic cell cycle in mammalian oocytes (Kimura et al. 2007). Phosphorylation and activation of Akt during oocyte maturation precedes GV breakdown in mouse oocytes (Kalous et al. 2006). The results of the present study regarding $A k t 1$ poly(A) transcripts are in agreement with this finding and with previous studies in which higher $A K T 1$ expression during IVM confirms that culture conditions can affect the molecular mechanisms controlling nuclear and cytoplasmic maturation (Cecconi et al. 2010). TP53 also has a crucial role in cell cycle regulation because it participates in the $\mathrm{G}_{1} / \mathrm{S}$ phase checkpoint and therefore in cell cycle arrest. TP53 is involved in DNA repair and regulates the expression of target genes, such as $C A S P 3$, leading to cell death through apoptosis when DNA damage occurs (Zheng et al. 2005b). The upregulation of Tp53 and Casp3 in IVM oocytes in the present study supports dysfunction in cell cycle regulation and suggests an increase in DNA repair mechanisms, leading to cell cycle arrest and apoptosis. SOD2 is involved in the oxidative response and mitochondrial activity because it encodes a mitochondrial protein that catalyses the dismutation of superoxide into $\mathrm{H}_{2} \mathrm{O}_{2}$. In the present study, we found a higher poly(A) mRNA abundance of Sod2 in IVM oocytes compared with those matured in vivo. This finding indicates higher oxidative stress in oocytes during IVM (Maître et al. 1993; Guérin et al. 2001) and may suggest a readenylation process involved in the regulation of the expression of this transcript, as described previously in mice and cattle (Brevini-Gandolfi et al. 1999). However, in CCs, opposite findings regarding gene abundance were made: Sod 2 mRNA was higher in CCs from in vivo-matured compared with IVM oocytes. CCs with higher SOD2 activity may effectively protect COCs against apoptosis caused by the generation of ROS. In fact, increased SOD2 activity in the follicular fluid has been associated with better oocyte quality in humans (Kably Ambe et al. 2004). This finding is in agreement with the lower apoptosis rates determined using the TUNEL assay in CCs from IVM COCs compared with those matured in vivo. In fact, it has been reported that the incidence of apoptosis in CCs during IVM reduces oocyte quality and induces the failure of meiotic maturation in gilts (Yuan et al. 2008), as well as impaired oocyte developmental competence in humans (Lee et al. 2001).

Glucose metabolism through the pentose phosphate pathway (PPP) is a primary factor for the progression of nuclear and cytoplasmic maturation through the provision of substrates for purine synthesis, such as phosphoribosylpyrophosphate (PRPP) and redox homeostasis (reduced nicotinamide adenine dinucleotide phosphate (NADPH) through reduction of glutathione (for a review, see Sutton-McDowall et al. 2010). This contributes to certain level of protection against oxidative stress-induced apoptosis in the oocyte (Combelles et al. 2009). In the present study, the gene encoding the enzyme that catalyses the first and irreversible step of the PPP pathway (G6pd) was upregulated in $\mathrm{CCs}$ after oocyte maturation and tended to be higher in in vivomatured CCs, implying a possible increase in the PPP pathway and higher redox protection (Downs et al. 1998; Kang et al. 2012). Moreover, G6pd was downregulated in oocytes after in vivo maturation compared with immature and IVM oocytes. 
Ovine (Wang et al. 2012) and rat (Tsutsumi et al. 1992) oocytes with decreased G6PD activity have been shown to have higher developmental competence as well. This finding corresponds to the lower potential PPP activity in MII oocytes reported in mice (Urner and Sakkas 1999; Dumollard et al. 2007).

Several authors have suggested that the glucose within COCs is essentially destined for the production of pyruvate and lactate, because both are the main preferred substrates for the oocyte. GAPDH catalyses the sixth step of anaerobic glycolysis, converting $\mathrm{NAD}^{+}$to $\mathrm{NADH}$ and thus generating reducing power. Increased abundance of the GAPDH transcript in both oocytes and CCs has been associated a higher oocyte competence after IVM in cattle (Bermejo-Álvarez et al. 2010; Gendelman and Roth 2012). Paradoxically, in the present study we found that Gapdh mRNA transcripts decreased slightly in CCs after in vivo maturation compared with CCs from immature GV oocytes. These differences between experimental groups dissuaded us from using this gene as an internal control in the quantitative analysis of gene expression, in contrast with previous reports in dogs (Cho et al. 2016), mice (Shao et al. 2015) and humans (Ouandaogo et al. 2012), but support previous findings in rabbit embryos (Arias-Álvarez et al. 2013a, 2013b), mouse oocytes (Jeong et al. 2005; Cui et al. 2007) and bovine oocytes (Bermejo-Álvarez et al. 2010; Adona et al. 2016). These controversial results indicate that the expression of $G A P D H$ could differ among species and this deserves further investigation.

With regard to the events accompanying cytoplasmic maturation, the present study has established, for the first time, mitochondrial distribution patterns in rabbit oocytes. The oocytes exhibited changes in mitochondrial organisation, ranging from a fine uniform distribution throughout the cytoplasm in immature GV oocytes to cortical distribution as maturation progressed with both IVM and in vivo maturation. The percentage of oocytes with migrated mitochondria was significantly lower after IVM than in vivo maturation. Furthermore, in IVM oocytes, mitochondria formed aggregates, whereas most in vivomatured MII oocytes had a cortical and homogeneous pattern of mitochondrial distribution. Although mitochondrial distribution patterns have been described in different species, including mice (Yu et al. 2010; Nazmara et al. 2014), pigs (Sun et al. 2001), cattle (Zhuang et al. 2012), horses (Torner et al. 2007), cats (De los Reyes et al. 2011) and humans (Guérin et al. 2001; Liu et al. 2010), it has been reported that homogeneous mitochondrial distribution is correlated with lower oxidative activity and with minor levels of CC apoptosis, whereas a clustered distribution is correlated with the opposite (Torner et al. 2004). Therefore, the high percentage of clustered mitochondrial patterns in IVM oocytes observed in the present study could contribute to the lower developmental potential of these oocytes compared with oocytes matured in vivo.

The findings of the present study are in agreement with the different kinetics of early cleavage divisions observed in embryos derived from in vivo-matured compared with IVM oocytes. Previous studies have demonstrated that the timing of the first cleavage divisions (Lonergan et al. 1999), activation of the embryonic genome at the 8- to 16-cell stage in rabbits and compaction of the morula determine the quality of embryos
(Rizos et al. 2008). Such events, especially those that sustain early embryo development until activation of the embryonic genome, are directly related to the intrinsic quality of the oocyte (Lonergan et al. 1999). In the present study, embryos derived from ovulated oocytes showed faster developmental speed and a higher percentage of presumptive zygotes that cleaved and developed to the morula stage, which provides clear evidences of the higher quality of these embryos (Gutiérrez-Adán et al. 2004; Rizos et al. 2008). These findings corroborate the results for the mRNA transcripts, mitochondrial distribution and rate of apoptosis of CCs in rabbit COCs in the present study.

\section{Conclusions}

The present study provides an original description of the cellular and molecular events during oocyte maturation in the rabbit model. Differences in the gene expression profile related to cumulus expansion, cell cycle regulation, apoptosis and oxidative stress; mitochondrial reallocation; and the cumulus apoptotic index between in vivo-matured and IVM rabbit COCs support the idea that the functions mediated by these genes could be compromised during IVM, producing MII oocytes of suboptimal quality. General increased mRNA poly(A) abundance in IVM oocytes suggests a failure to undergo the normal pattern of transcript silencing expected in good-quality oocytes and could explain the poor developmental competence of IVM versus in vivo-matured oocytes. In fact, embryos derived from in vivo-matured oocytes exhibited higher developmental ability during the first cleavage divisions than those derived from IVM oocytes. Among the genes studied in CCs, we consider the expression of Gjal as a possible non-invasive biomarker of oocyte developmental competence in this species. The findings of the present study set the basis for further investigations to improve IVM conditions and therefore contribute to the progress of in ARTs.

\section{Acknowledgements}

This work was supported by grants AGL-2011-23822, AGL2015-65572 and AGL2015-66145-R from the Spanish Ministry of Science and Technology, the Community of Madrid (S2013/ABI-2913) and UCM- CM research program (920249-2009). The authors thank D. Rizos, A. Sanchez and K. Nieto for their invaluable help with this work.

\section{References}

Adona, P. R., Leal, C. L., Biase, F. H., De Bem, T. H., Mesquita, L. G., Meirelles, F. V., Ferraz, A. L., Furlan, L. R., Monzani, P. S., and Guemra, S. (2016). In vitro maturation alters gene expression in bovine oocytes. Zygote 24, 624-633.

Adriaenssens, T., Wathlet, S., Segers, I., Verheyen, G., De Vos, A., Van der Elst, J., Coucke, W., Devroey, P., and Smitz, J. (2010). Cumulus cell gene expression is associated with oocyte developmental quality and influenced by patient and treatment characteristics. Hum. Reprod. 25, 1259-1270. doi:10.1093/HUMREP/DEQ049

Agca, C., Yakan, A., and Agca, Y. (2013). Estrus synchronization and ovarian hyper-stimulation treatments have negligible effects on cumulus oocyte complex gene expression whereas induction of ovulation causes major expression changes. Mol. Reprod. Dev. 80, 102-117. doi:10.1002/ MRD. 22141

Arias-Álvarez, M., García-García, R. M., Rebollar, P. G., Revuelta, L., Millán, P., and Lorenzo, P. L. (2009). Influence of metabolic status on 
oocyte quality and follicular characteristics at different postpartum periods in primiparous rabbit does. Theriogenology 72, 612-623. doi:10.1016/J.THERIOGENOLOGY.2009.04.017

Arias-Álvarez, M., García-García, R. M., Rebollar, P. G., Nicodemus, N., Millán, P., Revuelta, L., and Lorenzo, P. L. (2010). Follicular, oocyte and embryo features related to metabolic status in primiparous lactating does fed with high-fibre rearing diets. Reprod. Domest. Anim. 45, e91-e100.

Arias-Alvarez, M., García-García, R. M., Rebollar, P. G., Gutiérrez-Adán, A., López-Béjar, M., and Lorenzo, P. L. (2013a). Ovarian response and embryo gene expression patterns after nonsuperovulatory gonadotropin stimulation in primiparous rabbits does. Theriogenology 79, 323-330. doi:10.1016/J.THERIOGENOLOGY.2012.09.019

Arias-Álvarez, M., García-García, R. M., Lorenzo, P. L., Gutiérrez-Adán, A., Sakr, O. G., González-Bulnes, A., and Rebollar, P. G. (2013b). Embryo gene expression in response to maternal supplementation with glycogenic precursors in the rabbit. Anim. Reprod. Sci. 142, 173-182. doi:10.1016/J.ANIREPROSCI.2013.10.001

Assidi, M., Dufort, I., Ali, A., Hamel, M., Algriany, O., Dielemann, S., and Sirard, M. A. (2008). Identification of potential markers of oocyte competence expressed in bovine cumulus cells matured with folliclestimulating hormone and/or phorbolmyristate acetate in vitro. Biol. Reprod. 79, 209-222. doi:10.1095/BIOLREPROD.108.067686

Assou, S., Haouzi, D., De Vos, J., and Hamamah, S. (2010). Human cumulus cells as biomarkers for embryo and pregnancy outcomes. Mol. Hum. Reprod. 16, 531-538. doi:10.1093/MOLEHR/GAQ032

Bachvarova, R. (1985). Gene expression during oogenesis and oocyte development in mammals. Dev. Biol. (N. Y. 1985) 1, 453-524.

Bavister, B. D., and Squirrell, J. M. (2000). Mitochondrial distribution and function in oocytes and early embryos. Hum. Reprod. 15, 189-198. doi:10.1093/HUMREP/15.SUPPL_2.189

Bermejo-Álvarez, P., Lonergan, P., Rizos, D., and Gutiérrez-Adan, A. (2010). Low oxygen tension during IVM improves bovine oocyte competence and enhances anaerobic glycolysis. Reprod. Biomed. Online 20, 341-349. doi:10.1016/J.RBMO.2009.12.006

Blaha, M., Nemcova, L., Kepkova, K. V., Vodicka, P., and Prochazka, R. (2015). Gene expression analysis of pig cumulus-oocyte complexes stimulated in vitro with follicle stimulating hormone or epidermal growth factor-like peptides. Reprod. Biol. Endocrinol. 13, 113 doi:10.1186/S12958-015-0112-2

Boerboom, D., and Sirois, J. (1998). Molecular characterization of equine prostaglandin $\mathrm{G} / \mathrm{H}$ synthase-2 and regulation of its messenger ribonucleic acid in preovulatory follicles. Endocrinology 139, 1662-1670.

Brevini-Gandolfi, T. A., Favetta, L. A., Mauri, L., Luciano, A. M., Cillo, F. and Gandolfi, F. (1999). Changes in poly(A) tail length of maternal transcripts during in vitro maturation of bovine oocytes and their relation with developmental competence. Mol. Reprod. Dev. 52, 427-433. doi:10.1002/(SICI)1098-2795(199904)52:4<427::AID-MRD12>3.0 $\mathrm{CO} ; 2-\mathrm{G}$

Buccione, R., Schroeder, A. C., and Eppig, J. J. (1990). Interactions between somatic cells and germ cells throughout mammalian oogenesis. Biol. Reprod. 43, 543-547. doi:10.1095/BIOLREPROD43.4.543

Burnik Papler, T., Vrtacnik Bokal, E., Lovrecic, L., Kopitar, A. N., and Maver, A. (2015). No specific gene expression signature in human granulosa and cumulus cells for prediction of oocyte fertilisation and embryo implantation. PLoS One 10, e0115865. doi:10.1371/JOURNAL. PONE.0115865

Calder, M. D., Caveney, A. N., Smith, L. C., and Watson, A. J. (2003) Responsiveness of bovine cumulus-oocyte-complexes (COC) to porcine and recombinant human $\mathrm{FSH}$, and the effect of $\mathrm{COC}$ quality on gonadotropin receptor and $\mathrm{Cx} 43$ marker gene mRNAs during maturation in vitro. Reprod. Biol. Endocrinol. 1, 14-25. doi:10.1186/1477-7827$1-14$
Cecconi, S., Rossi, G., Santilli, A., Stefano, L. D., Hoshino, Y., Sato, E., Palmerini, M. G., and Macchiarelli, G. (2010). Akt expression in mouse oocytes matured in vivo and in vitro. Reprod. Biomed. Online 20, 35-41. doi:10.1016/J.RBMO.2009.10.011

Cho, S. J., Lee, K. L., Kim, Y. G., Kim, D. H., Yoo, J. G., Yang, B. C., Park, J. K., and Kong, I. K. (2016). Differential gene-expression profiles from canine cumulus cells of ovulated versus in vitro-matured oocytes. Reprod. Fertil. Dev. 28, 278-285. doi:10.1071/RD14086

Combelles, C. M. H., Gupta, S., and Agarwal, A. (2009). Could oxidative stress influence the in vitro maturation of oocytes? Reprod. Biomed. Online 18, 864-880. doi:10.1016/S1472-6483(10)60038-7

Cui, X. S., Li, X. Y., Yin, X. J., Kong, I. K., Kang, J. J., and Kim, N. H (2007). Maternal gene transcription in mouse oocytes: genes implicated in oocyte maturation and fertilization. J. Reprod. Dev. 53, 405-418. doi:10.1262/JRD.18113

Davis, B. J., Lennard, D. E., Lee, C. A., Tiano, H. F., Morham, S. G., Wetsel, W. C., and Langenbach, R. (1999). Anovulation in cyclooxygenase-2deficient mice is restored by prostaglandin $\mathrm{E}_{2}$ and interleukin-1beta Endocrinology 140, 2685-2695.

De los Reyes, M., Palomino, J., Parraguez, V. H., Hidalgo, M., and Saffie, P. (2011). Mitochondrial distribution and meiotic progression in canine oocytes during in vivo and in vitro maturation. Theriogenology $\mathbf{7 5}$ 346-353. doi:10.1016/J.THERIOGENOLOGY.2010.09.005

Downs, S. M., Humpherson, P. G., and Leese, H. J. (1998). Meiotic induction in cumulus cell-enclosed mouse oocytes: involvement of the pentose phosphate pathway. Biol. Reprod. 58, 1084-1094. doi:10.1095/ BIOLREPROD58.4.1084

Dumollard, R., Ward, Z., Carroll, J., and Duchen, M. R. (2007). Regulation of redox metabolism in the mouse oocyte and embryo. Development 134 455-465. doi:10.1242/DEV.02744

Dumollard, R., Carroll, J., Duchen, M. R., Campbell, K., and Swann, K. (2009). Mitochondrial function and redox state in mammalian embryos. Semin. Cell Dev. Biol. 20, 346-353. doi:10.1016/J.SEMCDB.2008. 12.013

Edry, I., Sela-Abramovich, S., and Dekel, N. (2006). Meiotic arrest of oocytes depends on cell-to-cell communication in the ovarian follicle. Mol. Cell. Endocrinol. 252, 102-106. doi:10.1016/J.MCE.2006.03.009

Eppig, J. J., Chesnel, F., Hirao, Y., O’Brien, M. J., Pendola, F. L., Watanabe, S., and Wigglesworth, K. (1997). Oocyte control of granulosa cell development: how and why. Hum. Reprod. 12, 127-132.

Feuerstein, P., Cadoret, V., Dalbies-Tran, R., Guerif, F., Bidault, R., and Royere, D. (2007). Gene expression in human cumulus cells: one approach to oocyte competence. Hum. Reprod. 22, 3069-3077. doi:10.1093/HUMREP/DEM336

Fischer, B., Chavatte-Palmer, P., Viebahn, C., Navarrete Santos, A., and Duranthon, V. (2012). Rabbit as a reproductive model for human health. Reproduction 144, 1-10. doi:10.1530/REP-12-0091

Foster, R., Segers, I., Smart, D., Adriaenssens, T., Smitz, J., Arce, J. C., and Princivalle, M. (2010). A differential cytokine expression profile is induced by highly purified human menopausal gonadotropin and recombinant follicle-stimulating hormone in a pre- and postovulatory mouse follicle culture model. Fertil. Steril. 93, 1464-1476. doi:10.1016/ J.FERTNSTERT.2009.01.136

Gendelman, M., and Roth, Z. (2012). In vivo vs. in vitro models for studying the effects of elevated temperature on the GV-stage oocyte, subsequen developmental competence and gene expression. Anim. Reprod. Sci. 134, 125-134. doi:10.1016/J.ANIREPROSCI.2012.07.009

Gittens, J. E., and Kidder, G. M. (2005). Differential contributions of connexin 37 and connexin 43 to oogenesis revealed in chimeric reaggregated mouse ovaries. J. Cell Sci. 118, 5071-5078. doi:10.1242/JCS. 02624

Guérin, P., El Mouatassim, S., and Ménézo, Y. (2001). Oxidative stress and protection against reactive oxygen species in the pre-implantation 
embryo and its surroundings. Hum. Reprod. Update 7, 175-189. doi:10.1093/HUMUPD/7.2.175

Gutiérrez-Adán, A., Rizos, D., Fair, T., Moreira, P. N., Pintado, B., de la Fuente, J., Boland, M. P., and Lonergan, P. (2004). Effect of speed of development on mRNA expression pattern in early bovine embryos cultured in vivo or in vitro. Mol. Reprod. Dev. 68, 441-448. doi:10.1002/ MRD.20113

Hasegawa, J., Yanaihara, A., Iwasaki, S., Mitsukawa, K., Negishi, M., and Okai, T. (2007). Reduction of connexin 43 in human cumulus cells yields good embryo competence during ICSI. J. Assist. Reprod. Genet. 24, 463-466. doi:10.1007/S10815-007-9155-4

Jang, Y. J., Park, J. I., Moon, W. J., Dam, P. T., Cho, M. K., and Chun, S. Y. (2015). Cumulus cell-expressed type I interferons induce cumulus expansion in mice. Biol. Reprod. 92, 20. doi:10.1095/BIOLREPROD. 114.122770

Jelíanková, L., Kubelka, M., Motlík, J., and Guerrier, P. (1994). Chromatin condensation and histone $\mathrm{H} 1$ kinase activity during growth and maturation of rabbits oocytes. Mol. Reprod. Dev. 37, 210-215. doi:10.1002/ MRD.1080370212

Jeong, Y. J., Choi, H. W., Shin, H. S., Cui, X. S., Kim, N. H., Gerton, G. L., and Jun, J. H. (2005). Optimization of real time RT-PCR methods for the analysis of gene expression in mouse eggs and preimplantation embryos. Mol. Reprod. Dev. 71, 284-289. doi:10.1002/MRD.20269

Jones, G. M., Cram, D. S., Song, B., Magli, M. C., Gianaroli, L., LachamKaplan, O., Findlay, J. K., Jenkin, G., and Trounson, A. O. (2008). Gene expression profiling of human oocytes following in vivo or in vitro maturation. Hum. Reprod. 23, 1138-1144. doi:10.1093/HUMREP/ DEN085

Kably Ambe, A., Ruiz Anguas, J., Carballo Mondragón, E., Corona de Lau, C., and Karchmerand Krivitsky, S. (2004). [Correlation between follicle levels of superoxide dismutase and oocyte quality, fertilization rates and embryo development.] Ginecol. Obstet. Mex. 72, 335-344. [In Spanish]

Kalous, J., Solc, P., Baran, V., Kubelka, M., Schultz, R. M., and Motlik, J. (2006). $\mathrm{PKB} / \mathrm{AKT}$ is involved in resumption of meiosis in mouse oocytes. Biol. Cell 98, 111-123. doi:10.1042/BC20050020

Kang, J. T., Atikuzzaman, M., Kwon, D. K., Park, S. J., Kim, S. J., Moon, J. H., Koo, O. J., Jang, G., and Lee, B. C. (2012). Developmental competence of porcine oocytes after in vitro maturation and in vitro culture under different oxygen concentrations. Zygote 20, 1-8. doi:10.1017/S0967199411000426

Kimura, N., Hoshino, Y., Totsukawa, K., and Sato, E. (2007). Cellular and molecular events during oocyte maturation in mammals: molecules of cumulus-oocyte complex matrix and signalling pathways regulating meiotic progression. Soc. Reprod. Fertil. Suppl. 63, 327-342.

Kohata, C., Izquierdo-Rico, M. J., Romar, R., and Funahashi, H. (2013). Development competence and relative transcript abundance of oocytes derived from small and medium follicles of prepubertal gilts. Theriogenology 80, 970-978. doi:10.1016/J.THERIOGENOLOGY.2013. 07.023

Lee, K. S., Joo, B. S., Na, Y. J., Yoon, M. S., Choi, O. H., and Kim, W. W. (2001). Cumulus cells apoptosis as an indicator to predict the quality of oocytes and the outcome of IVF-ET. J. Assist. Reprod. Genet. 18, 490-498. doi:10.1023/A:1016649026353

Li, S. H., Lin, M. H., Hwu, Y. M., Lu, C. H., Yeh, L. Y., Chen, Y. J., and Lee, R. K. (2015). Correlation of cumulus gene expression of GJA1, PRSS35, PTX3, and SERPINE2 with oocyte maturation, fertilization, and embryo development. Reprod. Biol. Endocrinol. 13, 93. doi:10.1186/S12958015-0091-3

Liu, S., Li, Y., Gao, X., Yan, J.-H., and Chen, Z.-J. (2010). Changes in the distribution of mitochondria before and after in vitro maturation of human oocytes and the effect of in vitro maturation on mitochondria distribution. Fertil. Steril. 93, 1550-1555. doi:10.1016/J.FERTN STERT.2009.03.050
Lonergan, P., Khatir, H., Piumi, F., Rieger, D., Humblot, P., and Boland, M. P. (1999). Effect of time interval from insemination to first cleavage on the developmental characteristics, sex ratio and pregnancy rate after transfer of bovine embryos. J. Reprod. Fertil. 117, 159-167. doi:10.1530/JRF.0.1170159

Lord, C. E., Dauphinee, A. N., Watts, R. L., and Gunawardena, A. H. (2013). Unveiling interactions among mitochondria, caspase-like proteases, and the actin cytoskeleton during plant programmed cell death (PCD). PLoS One 8, e57110. doi:10.1371/JOURNAL.PONE.0057110

Lorenzo, P. L., Rebollar, P. G., Illera, M. J., Illera, J. C., Illera, M., and Alvariño, J. M. (1996). Stimulatory effect of insulin-like growth factor I and epidermal growth factor on the maturation of rabbit oocytes in vitro. J. Reprod. Fertil. 107, 109-117. doi:10.1530/JRF.0.1070109

Maître, B., Jornot, L., and Junod, A. F. (1993). Effects of inhibition of catalase and superoxide dismutase activity on antioxidant enzyme mRNA levels. Am. J. Physiol. 265, L636-L643.

McKenzie, L. J., Pangas, S. A., Carson, S. A., Kovanci, E., Cisneros, P., Buster, J. E., Amato, P., and Matzuk, M. M. (2004). Human cumulus granulosa cell gene expression: a predictor of fertilization and embryo selection in women undergoing IVF. Hum. Reprod. 19, 2869-2874. doi:10.1093/HUMREP/DEH535

Nazmara, Z., Salehnia, M., and HosseinKhani, S. (2014). Mitochondrial distribution and ATP content of vitrified, in vitro matured mouse oocytes. Avicenna J. Med. Biotechnol. 6, 210-217.

Nivet, A. L., Vigneault, C., Blondin, P., and Sirard, M. A. (2013). Changes in granulosa cells' gene expression associated with increased oocyte competence in bovine. Reproduction 145, 555-565. doi:10.1530/REP13-0032

Nuttinck, F., Reinaud, P., Tricoire, H., Vigneron, C., Peynot, N., Mialot, J. P., Mermillod, P., and Charpigny, G. (2002). Cyclooxygenase-2 is expressed by cumulus cells during oocyte maturation in cattle. Mol. Reprod. Dev. 61, 93-101. doi:10.1002/MRD.1135

Ouandaogo, Z. G., Frydman, N., Hesters, L., Assou, S., Haouzi, D., Dechaud, H., Frydman, R., and Hamamah, S. (2012). Differences in transcriptomic profiles of human cumulus cells isolated from oocytes at $\mathrm{GV}, \mathrm{MI}$ and MII stages after in vivo and in vitro oocyte maturation. Hum. Reprod. 27, 2438-2447. doi:10.1093/HUMREP/DES172

Paynton, B. V., and Bachvarova, R. (1994). Polyadenylation and deadenylation of maternal mRNAs during oocyte growth and maturation in the mouse. Mol. Reprod. Dev. 37, 172-180. doi:10.1002/MRD. 1080370208

Rizos, D., Clemente, M., Bermejo-Alvarez, P., de La Fuente, J., Lonergan, P., and Gutiérrez-Adán, A. (2008). Consequences of in vitro culture conditions on embryo development and quality. Reprod. Domest. Anim. 43, 44-50. doi:10.1111/J.1439-0531.2008.01230.X

Schmittgen, T. D., and Livak, K. J. (2008). Analysing real-time PCR data by the comparative C(T) method. Nat. Protoc. 3, 1101-1108. doi:10.1038/ NPROT.2008.73

Shao, L., Chian, R. C., Xu, Y., Yan, Z., Zhang, Y., Gao, C., Gao, L., Liu, J., and Cui, Y. (2015). Genomic expression profiles in cumulus cells derived from germinal vesicle and MII mouse oocytes. Reprod. Fertil. Dev. doi:10.1071/RD15077

Sirard, M. A. (2001). Resumption of meiosis: mechanism involved in meiotic progression and its relation with developmental competence. Theriogenology 55, 1241-1254. doi:10.1016/S0093-691X(01)00480-0

Smitz, J., Andersen, A. N., Devroey, P., and Arce, J. C. (2007). Endocrine profile in serum and follicular fluid differs after ovarian stimulation with HP-hMG or recombinant FSH in IVF patients. Hum. Reprod. 22, 676-687. doi:10.1093/HUMREP/DEL445

Stojkovic, M., Machado, S. A., Stojkovic, P., Zakhartchenko, V., Hutzler, P., Gonçalves, P. B., and Wolf, E. (2001). Mitochondrial distribution and adenosine triphosphate content of bovine oocytes before and after in vitro maturation: correlation with morphological criteria and 
developmental capacity after in vitro fertilization and culture. Biol. Reprod. 64, 904-909. doi:10.1095/BIOLREPROD64.3.904

Sun, Q. Y., Wu, G. M., Lai, L., Park, K. W., Cabot, R., Cheong, H. T., Day, B. N., Prather, R. S., and Schatten, H. (2001). Translocation of active mitochondria during pig oocyte maturation, fertilization and early embryo development in vitro. Reproduction 122, 155-163. doi:10.1530/REP.0.1220155

Sutton-McDowall, M. L., Gilchrist, R. B., and Thompson, J. G. (2010). The pivotal role of glucose metabolism in determining oocyte developmental competence. Reproduction 139, 685-695. doi:10.1530/REP-09-0345

Tesfaye, D., Ghanem, N., Carter, F., Fair, T., Sirard, M. A., Hoelker, M. Schellander, K., and Lonergan, P. (2009). Gene expression profile of cumulus cells derived from cumulus-oocyte complexes matured either in vivo or in vitro. Reprod. Fertil. Dev. 21, 451-461. doi:10.1071/ RD08190

Thouas, G. A., Trounson, A. O., Wolvetang, E. J., and Jones, G. M. (2004). Mitochondrial dysfunction in mouse oocytes results in preimplantation embryo arrest in vitro. Biol. Reprod. 71, 1936-1942. doi:10.1095/ BIOLREPROD.104.033589

Torner, H., Brüsow, K., Alm, H., Ratky, J., Pöhland, R., Tuchscherer, A., and Kamitz, W. (2004). Mitochondrial aggregation patterns and activation in porcine oocytes and apoptosis in surrounding cumulus cells depends on the stage of pre-ovulatory maturation. Theriogenology 61, 1675-1689. doi:10.1016/J.THERIOGENOLOGY.2003.09.013

Torner, H., Alm, H., Kanitz, W., Goellnitz, K., Becker, F., Poehland, R., Bruessow, K. P., and Tuchscherer, A. (2007). Effect of initial cumulus morphology on meiotic dynamic and status of mitochondria in horse oocytes during IVM. Reprod. Domest. Anim. 42, 176-183. doi:10.1111/ J.1439-0531.2006.00749.X

Tsutsumi, O., Satoh, K., Taketani, Y., and Kato, T. (1992). Determination of enzyme activities of energy metabolism in the maturing rat oocyte. Mol. Reprod. Dev. 33, 333-337. doi:10.1002/MRD.1080330315

Urner, F., and Sakkas, D. (1999). Characterization of glycolysis and pentose phosphate pathway activity during sperm entry into the mouse oocyte. Biol. Reprod. 60, 973-978. doi:10.1095/BIOLREPROD60.4.973

Van Blerkom, J. (2011). Mitochondrial function in the human oocyte and embryo and their role in developmental competence. Mitochondrion 11, 797-813. doi:10.1016/J.MITO.2010.09.012

Viudes-de-Castro, M. P., Moce, E., Vicente, J. S., Marco-Jimenez, S., and Lavara, R. (2005). In vitro evaluation of in vivo fertilizing ability of frozen rabbit semen. Reprod. Domest. Anim. 40, 136-140. doi:10.1111/ J.1439-0531.2005.00568.X

Wang, H. L., Sui, H. S., Liu, Y., Miao, D. Q., Lu, J. H., Liang, B., and Tan, J. H. (2009). Dynamic changes of germinal vesicle chromatin configuration and transcriptional activity during maturation of rabbit follicles. Fertil. Steril. 91, 1589-1594. doi:10.1016/J.FERTNSTERT. 2008.10.071

Wang, L., Lin, J., Huang, J., Wang, J., Zhao, Y., and Chen, T. (2012). Selection of ovine oocytes by brilliant cresyl blue staining. J. Biomed. Biotechnol. 2012, 161372. doi:10.1155/2012/161372

Wathlet, S., Adriaenssens, T., Segers, I., Verheyen, G., Van de Velde, H., Coucke, W., Ron El, R., Devroey, P., and Smitz, J. (2011). Cumulus cell gene expression predicts better cleavage-stage embryo or blastocyst development and pregnancy for ICSI patients. Hum. Reprod. 26, 10351051. doi:10.1093/HUMREP/DER036

Wilding, M., Dale, B., Marino, M., di Matteo, L., Alviggi, C., Pisaturo, M. L., Lombardi, L., and De Placido, G. (2001). Mitochondrial aggregation patterns and activity in human oocytes and preimplantation embryos. Hum. Reprod. 16, 909-917. doi:10.1093/HUMREP/16.5.909

Yu, Y., Dumollard, R., Rossbach, A., Lai, F., and Swann, K. (2010). Redistribution of mitochondria leads to bursts of ATP production during spontaneous mouse oocyte maturation. J. Cell. Physiol. 224, 672-680. doi:10.1002/JCP.22171

Yuan, Y., Hao, Z. D., Liu, J., Wu, Y., Yang, L., Liu, G. S., Tian, J. H., Zhu, S. E., and Zeng, S. M. (2008). Heat shock at the germinal vesicle breakdown stage induces apoptosis in surrounding cumulus cells and reduces maturation rates of porcine oocytes in vitro. Theriogenology $\mathbf{7 0}$ 168-178. doi:10.1016/J.THERIOGENOLOGY.2008.03.005

Zeng, S. M., Zhu, S. E., Wang, Y. S., Chen, X. J., Zhang, Z. C., and Chen, Y. F. (1999). An efficient method for in vitro fertilization in rabbits. Anim. Biotechnol. 10, 15-23. doi:10.1080/10495399909525918

Zheng, P., Patel, B., McMenamin, M., Moran, E., Paprocki, A. M., Kihara, M., Schramm, R. D., and Latham, K. E. (2005a). Effects of follicle size and oocyte maturation conditions on maternal messenger RNA regulation and gene expression in rhesus monkey oocytes and embryos. Biol. Reprod. 72, 890-897. doi:10.1095/BIOLREPROD.104. 035881

Zheng, P., Schramm, R. D., and Latham, K. E. (2005b). Developmental regulation and in vitro culture effects on expression of DNA repair and cell cycle checkpoint control genes in rhesus monkey oocytes and embryos. Biol. Reprod. 72, 1359-1369. doi:10.1095/BIOLREPROD. 104.039073

Zhuang, X.-J., Huang, Y., Duan, Y.-P., Zhang, M., Lu, Y.-Q., and Lu, K.-H. (2012). Translocation of active mitochondria during buffalo (Bubalus bubalis) oocytes in vitro maturation, fertilization and preimplantation embryo development. Reprod. Domest. Anim. 47, 443-448. doi:10.1111/ J.1439-0531.2011.01900.X 